CLINICAL STUDY

\title{
Evaluation of a standardized short-time calcium suppression test in healthy subjects: interest for the diagnosis of primary hyperparathyroidism
}

\author{
Isabelle Titon $^{1}$, Anne Cailleux-Bounacer ${ }^{1}$, Jean Pierre Basuyau ${ }^{2}$, Hervé Lefebvre ${ }^{1,3}$, Adeline Savouré ${ }^{1}$ \\ and Jean Marc Kuhn ${ }^{1,3}$ \\ ${ }^{1}$ Department of Endocrinology, Clinical Research Center INSERM 0204, Rouen University Hospital, Rouen, France, ${ }^{2}$ Laboratory of Clinical Biology, Henri \\ Becquerel Center and ${ }^{3}$ INSERM U413, Rouen University, Rouen, France
}

(Correspondence should be addressed to J M Kuhn who is now at Department of Endocrinology, Hôpital de Bois Guillaume, 147 Avenue du Maréchal Juin, 76230 Bois Guillaume, France; Email: jean-marc.kuhn@chu-rouen.fr)

\begin{abstract}
Objective: The diagnosis of primary hyperparathyroidism (PHP) can be difficult in patients with normal plasma calcium or parathyroid hormone (PTH) levels. We perfected a standardized short-time i.v. calcium loading test in healthy controls (HC) and compared the results with those of patients with PHP. Methods: Sixteen HC received $0.33 \mathrm{mmol} / \mathrm{kg}$ calcium gluconate intravenously for $3 \mathrm{~h}$. Plasma calcium and serum PTH levels (assayed with immunoluminescent sandwich methods) were measured before, at the end of the infusion and $3 \mathrm{~h}$ later. Results were compared with those of $16 \mathrm{PHP}$ patients. Results: In $\mathrm{HC}$, basal total plasma calcium (mean \pm s.e.m.) was $2.33 \pm 0.02 \mathrm{mmol} / \mathrm{l}$. At the end of calcium loading, calcemia reached $3.21 \pm 0.05 \mathrm{mmol} / \mathrm{l}$ and decreased to $2.94 \pm 0.08 \mathrm{mmol} / \mathrm{l} 3 \mathrm{~h}$ later. In PHP patients, basal plasma calcium was $2.54 \pm 0.03 \mathrm{mmol} / \mathrm{l}$ and reached similar values as in $\mathrm{HC}$ during the testing. Basal serum PTH levels were $32.5 \pm 3.3 \mathrm{ng} / \mathrm{l} \mathrm{in} \mathrm{HC}$ and $86.9 \pm 6.3 \mathrm{ng} / \mathrm{l}$ in PHP. At the end of calcium loading, they dropped to $8.8 \pm 0.6 \mathrm{ng} / \mathrm{l}(\mathrm{HC})$ and to $31.4 \pm 4.2 \mathrm{ng} / \mathrm{l}$ (PHP). Three hours later, they were $11.6 \pm 0.8$ and $39.8 \pm 4.0 \mathrm{ng} / \mathrm{l}$ respectively. There was a cut-off in serum PTH values between the two groups at the end of calcium loading and $3 \mathrm{~h}$ later.

Conclusion: The standardized short-time PTH suppression test appears reliable to differentiate healthy subjects from PHP whose serum PTH levels remain $>14$ and $>23 \mathrm{ng} / \mathrm{ml}$ respectively at the end of loading and $3 \mathrm{~h}$ later. This well-tolerated and easily performed test could be used for the diagnosis of PHP in patients suspected for the disease despite the normality of some basal biological markers.
\end{abstract}

European Journal of Endocrinology 157 351-357

\section{Introduction}

Primary hyperparathyroidism (PHP), the most frequent cause of hypercalcemia in outpatients, occurs in about 1 out of 1000 adults. Without treatment about $25 \%$ of patients have a progressive disease that can lead to severe complications such as kidney stones, renal failure or osteoporosis (1). By now, PHP is usually suspected in asymptomatic patients (2) on the basis of the association of incidentally discovered hypercalcemia and unsuppressed plasma parathyroid hormone (PTH) levels. However, the complete biological pattern of PHP is lacking in some cases. Some PHP patients display either normal calcemia $(3,4)$ or normal plasma PTH levels (5). In such cases, the diagnosis of PHP is not easily established on basal data but cannot be unrecognized on account of the potential complications of the disease (6-8). As in normal parathyroid cells, calcium-sensing receptors are present in the plasma membrane of parathyroid adenoma cells
(9-11). However, adenomatous parathyroid cells appear less sensitive to the negative feedback of calcium than normal parathyroid cells (12-14). The molecular basis of this relative insensitivity was attributed to either a decrease in the number of calcium-sensing receptors, an alteration in the transduction system, or both $(10,15,16)$. On this basis, a PTH suppression test using calcium loading has been proposed in order to differentiate PHP patients from subjects with normal parathyroid function (17). Several modalities have been described $(12,18-23)$ and different markers have been proposed as phosphate clearance (24), urinary cyclic AMP (17), or immunoreactive PTH $(12,18,19,21-23)$. However, no standardized test is presently available. The aim of the present study was to evaluate a standardized i.v. calcium loading for suppression of PTH secretion in a group of healthy volunteers. The results were compared with those obtained using a similar procedure in a group of patients with proven PHP. 


\section{Subjects and methods}

This open study was approved by the Ethics Committee of Haute Normandie (CCPPRB-HN). The subjects studied were divided into two groups.

Sixteen healthy controls (HC), 13 men, 3 women aged 19-69 years, were included after written informed consent. They had no history of the disease and were not taking any medication. They were under normal diet containing 800-1200 mg calcium per day. The total and ionized plasma calcium, phosphorus, serum albumin, $24 \mathrm{~h}$ calciuria, creatinine clearance (calculated using the Cockroft and Gault formula), plasma vitamin D, and serum PTH levels were normal.

The PHP group included 16 patients ( 4 men and 12 women) aged 31-74 years, placed under a normal diet as in controls. They were taking no medication. Among the 10 postmenopausal women, none were taking a hormone substitution. PHP was suspected on either mild hypercalcemia with normal serum PTH levels or on elevated serum PTH despite normal plasma calcium levels. An increase in $24 \mathrm{~h}$ calciuria was found in each case. Because they had a dissociated biological pattern, a calcium loading was included in their investigation testing. Their creatinine clearance (calculated as in healthy volunteers) was normal for age. 25-OH vitamin D plasma levels, measured in half of the patients, were in the normal range $(30-120 \mathrm{nmol} / \mathrm{l})$. The diagnosis of PHP was confirmed by the pathological examination of the parathyroid tissue removed during surgery. PHP was linked to a single parathyroid adenoma (adenoma size: $8-25 \mathrm{~mm}$ ) in 12 patients or to parathyroid hyperplasia in 4 patients. Three of the latter patients suffered from a multiple endocrine neoplasia type 1 (MEN1).

Calcium loading test was performed in non-fasting subjects placed in recumbency. At $0800 \mathrm{~h}$ two catheters were placed in peripheral veins of the right and left arms for blood sampling and calcium infusion respectively. Then $0.33 \mathrm{mmol} / \mathrm{kg}$ of $10 \%$ calcium gluconate were added to $0.9 \% \mathrm{NaCl}$ in order to obtain a total volume of $500 \mathrm{ml}$ which was infused in $3 \mathrm{~h}$. Blood was drawn before and at the end of calcium infusion, and $3 \mathrm{~h}$ later to measure plasma calcium, phosphorus, and serum PTH levels.

The plasma calcium and phosphorus levels were measured using the usual automated techniques of the laboratory. Plasma ionized calcium level was measured in $\mathrm{HC}$ with an electrochemical method using a selective electrode specific for calcium. Serum PTH levels were determined using an immuno-luminescent sandwich assay (Advantage I-PTH, Nichols, San Clemente, CA, USA). This immunoassay detects equally both 1-84 PTH and its large fragment 7-84. In controls and in seven PHP patients, the serum PTH levels were also measured using the bio-intact immunoassay exclusively directed against the intact 1-84 PTH (Bio-intact-PTH (bi-PTH), Nichols). The sensitivity of these two assays is $1 \mathrm{ng} / \mathrm{ml}$ and the normal ranges proposed by the manufacturer are between 10 and $60 \mathrm{ng} / \mathrm{l}$ and 10 and $46 \mathrm{ng} / \mathrm{l}$ respectively. PTH assays were performed between 2001 and 2005 ends in PHP patients and in December 2004 in HC.

\section{Statistical analysis}

Statistical analysis used the Mann-Whitney test for a comparison between groups of the values of the biological parameters measured at each time. The Bonferroni correction was used after performing three successive tests. The level of statistical significance was $0.05 / 3=0.017$ for each test. A receiver operating characteristic (ROC) curve was established and Fisher's exact test was used for the statistical evaluation of the cut-off values between the two groups studied. Correlations between plasma calcium and serum PTH levels were examined by linear regression study after verification that distribution of sample values was not precluded. The level of statistical significance was 0.05.

\section{Results}

The overall clinical tolerance of the test was good. Three $\mathrm{HC}$ complained of mild nausea at the end of the calcium infusion. Blood pressure moderately and transiently increased in three controls at the same time. These symptoms, linked to hypercalcemia, disappeared rapidly and spontaneously.

Basal calcemia (mean \pm s.e.m.), corrected as a function of plasma albumin levels, was $2.33 \pm 0.02$ and $2.54 \pm 0.03 \mathrm{mmol} / \mathrm{l}$ in $\mathrm{HC}$ and in PHP respectively (Table 1). Out of the 16 PHP patients, 11 had a serum calcium level in the normal range $(2.2-2.6 \mathrm{mmol} / \mathrm{l}$, Fig. 1). At the end of the calcium infusion, calcemia rose to $3.21 \pm 0.05 \mathrm{mmol} / \mathrm{l}(\mathrm{HC})$ and $3.44 \pm 0.06 \mathrm{mmol} / \mathrm{l}$ (PHP). Three hours after the calcium infusion was stopped, calcemia decreased to $2.94 \pm 0.08 \mathrm{mmol} / \mathrm{l}$ (HC) and $2.96 \pm 0.08 \mathrm{mmol} / \mathrm{l}$ (PHP). There was no statistical difference in the values of calcemia between

Table 1 Biological parameters (individual lowest and highest value) measured in basal conditions in healthy volunteers and in patients with primary hyperparathyroidism. Median is indicated in brackets.

\begin{tabular}{lcc}
\hline & $\begin{array}{c}\text { Healthy } \\
\text { controls }\end{array}$ & $\begin{array}{c}\text { Primary } \\
\text { hyperparathyroidism }\end{array}$ \\
\hline $\begin{array}{c}\text { Total plasma } \\
\text { calcium }\end{array}$ & $2.2-2.45(2.32)$ & $2.35-2.68(2.53)$ \\
$\begin{array}{l}\text { lonized plasma } \\
\text { calcium }\end{array}$ & $1.1-1.27(1.21)$ & \\
$\begin{array}{l}\text { Plasma phosphorus } \\
\text { Serum 1-84+7-84 }\end{array}$ & $\begin{array}{c}0.87-1.5(1.36) \\
\text { PTH }\end{array}$ & $\begin{array}{c}0.58-1.39(0.89) \\
\text { PTH }\end{array}$ \\
$\begin{array}{l}\text { Serum 1-84 PTH } \\
\text { Plasma 25 OH } \\
\text { vitamin D }\end{array}$ & $8-26(18)$ & $46-139(86)$ \\
Plasma creatinine & $66-115(80)$ & $42-76(51)$ \\
\hline
\end{tabular}



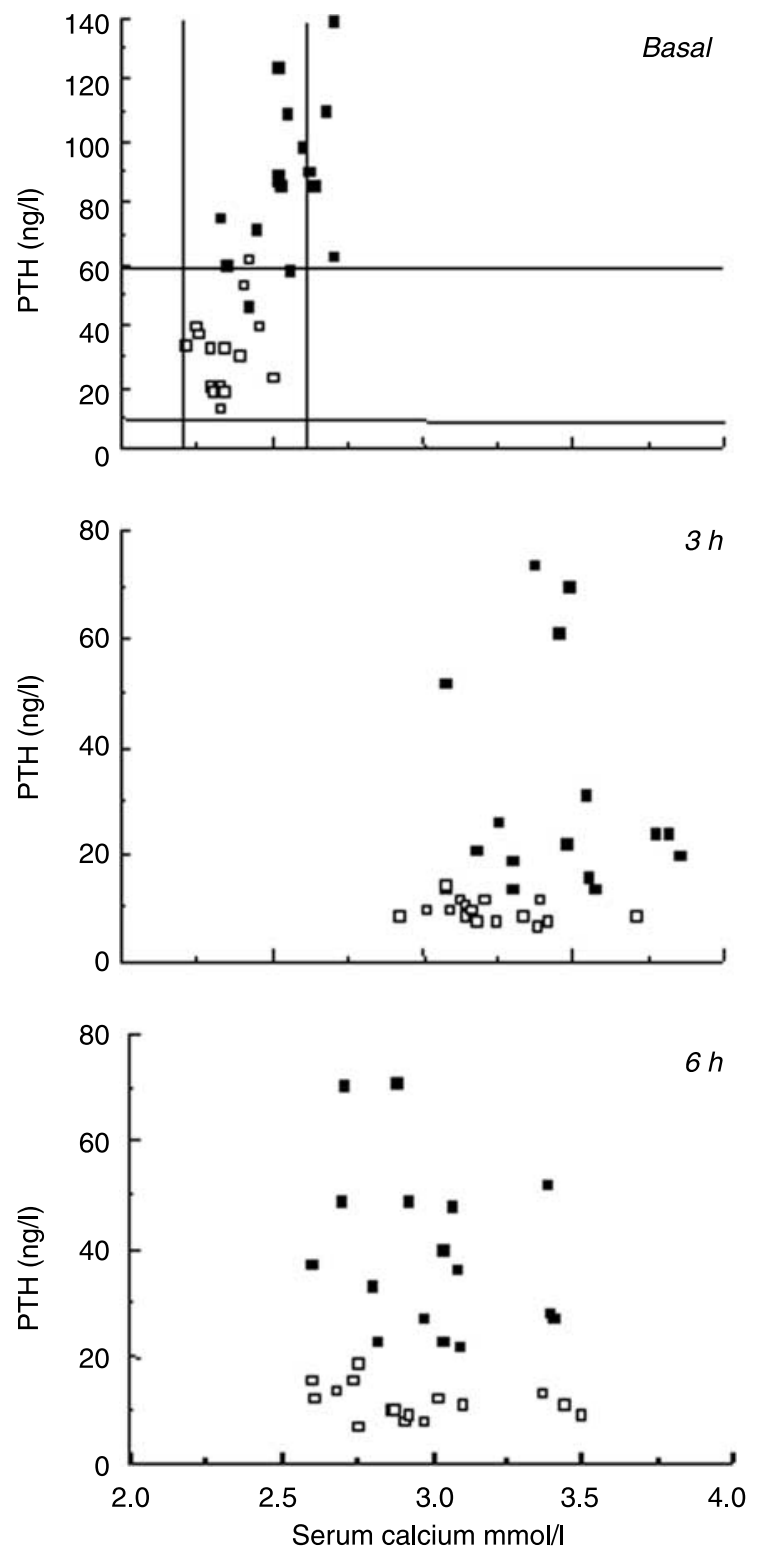

Figure 1 Plasma calcium and serum PTH levels in healthy volunteers (open squares) and patients with primary hyperparathyroidism (dark squares) before (basal), at the end of calcium loading $(3 \mathrm{~h})$, and $3 \mathrm{~h}$ after the end of the calcium infusion $(6 \mathrm{~h})$. On basal graph, horizontal and vertical lines indicate the limits of normal values for serum PTH and plasma calcium levels.

the two groups, neither at the end of calcium infusion nor $3 \mathrm{~h}$ later.

In $\mathrm{HC}$, ionized calcium level rose from $1.20 \pm 0.015$ to $1.78 \pm 0.02 \mathrm{mmol} / \mathrm{l}$ and was $1.50 .025 \mathrm{mmol} / \mathrm{l}$ at the end of the test. Ionized and total calcemia were strongly correlated ( $r=0.99, P<0.001$, Fig. 2).

Basal plasma phosphorus levels were $1.25 \pm 0.05$ (HC) and $0.87 \pm 0.04$ (PHP; $P<0.01$ ). They rose to $1.55 \pm 0.04$ and $1.15 \pm 0.03 \mathrm{mmol} / \mathrm{l}$ respectively during calcium loading.

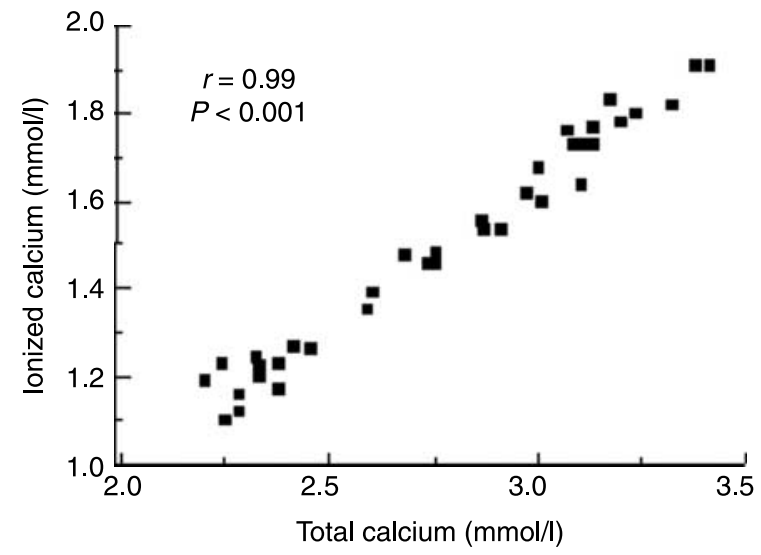

Figure 2 Correlation between total and ionized plasma calcium in healthy controls.

Basal serum PTH levels (mean \pm s.E.м.) were $32.5 \pm 3.3$ and $86.9 \pm 6.3 \mathrm{ng} / \mathrm{l}$ in the control group and PHP respectively $(P<0.01)$. Of the 16 PHP patients, 13 had a serum PTH level above the normal range (10-60 ng/l, Fig. 1). At the end of calcium infusion, serum PTH level decreased to $8.8 \pm 0.6 \mathrm{ng} / \mathrm{l}$ $(\mathrm{HC})$ and to $31.4 \pm 4.2 \mathrm{ng} / \mathrm{l}(\mathrm{PHP} ; \mathrm{P}<0.01)$. There was no overlap in individual values between controls and subjects with sporadic PHP whose serum PTH levels remained respectively lower and higher than $15 \mathrm{ng} / \mathrm{l}$ at the end of calcium loading. In the three patients with MEN1-related PHP, serum PTH levels dropped to $14 \mathrm{ng} / \mathrm{l}$. Three hours after the end of calcium infusion, serum PTH rose slightly to $11.6 \pm 0.8 \mathrm{ng} / \mathrm{l}(\mathrm{HC})$ and to $39.8 \pm 4.0 \mathrm{ng} / \mathrm{l}$ (PHP). Again, there was no overlap in individual values between controls and patients with sporadic PHP whose serum PTH levels were below 20 and above $26 \mathrm{ng} / \mathrm{l}$ respectively. In the three patients with MEN1, serum PTH levels reached 22, 23, and $23 \mathrm{ng} / \mathrm{l}$. Using PTH levels, the ROC curve constructed with the data obtained at the end of the calcium infusion (third hour of testing) gave a specificity of $93 \%$ and a sensitivity of $100 \%$ for the cut-off value of $12 \mathrm{ng} / \mathrm{l}$. With a cut-off value of $14 \mathrm{ng} / \mathrm{l}$ both sensitivity and specificity were $92 \%$. The ROC curve established with the data obtained at the end of the test (sixth hour of testing) gave a specificity and a sensitivity of $100 \%$ for the cut-off value of $20 \mathrm{ng} / \mathrm{l}$ (Fig. 3). Considering the number of subjects in each group, the confidence interval ranged from 80 to $100 \%$.

In subjects considered as a whole, serum bi-PTH (1-84) and i-PTH (1 and 7-84) levels were strongly correlated ( $r=0.98, P<0.001$, Fig. 4$)$.

\section{Discussion}

The spontaneous evolution of PHP, the most frequent cause of hypercalcemia in outpatients, is responsible for severe complications such as osteoporosis $(25,26)$, kidney stones, and renal involvement in about one-fifth 


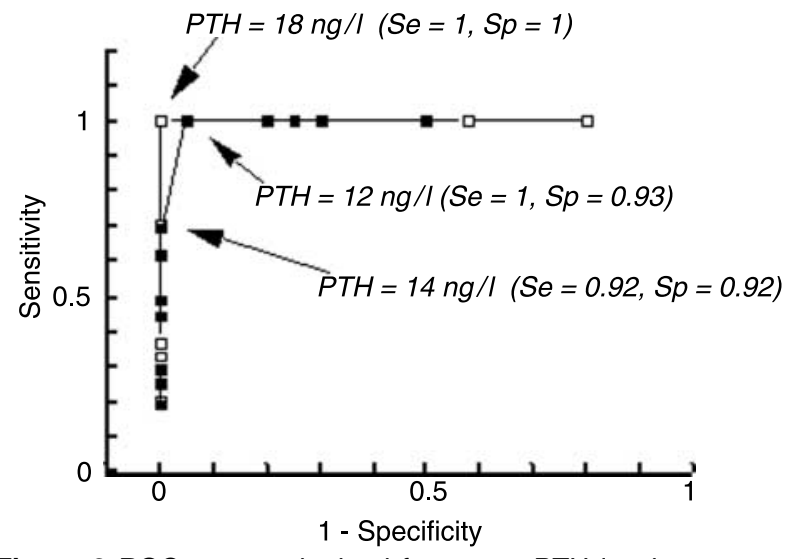

Figure $3 \mathrm{ROC}$ curves obtained for serum PTH levels measured either at the end (dark squares) or after the end of calcium loading (open squares).

of cases (1). The main goal of the treatment is to prevent the occurrence of such complications. Consensus conferences established the criteria for surgical treatment of PHP. They include calcemia $0.25 \mathrm{mmol} / \mathrm{l}$ above the upper limit of normal range or calciuria higher than $10 \mathrm{mmol} / 24 \mathrm{~h}$ (27-29). Most of the PHP are currently suspected in asymptomatic patients (2) on routine laboratory analysis revealing mild hypercalcemia and unsuppressed PTH levels. However, the complete biological pattern of PHP is lacking in some cases despite normal creatinine clearance and vitamin D status. Indeed, patients with PHP may present with either normocalcemia $(3,4)$ or more frequently normal serum PTH levels (5). In such cases, a dynamic PTH suppression test, using a calcium load, can provide further information for the diagnosis of PHP $(12,18-$ 23). Indeed, calcium-sensing receptors are present in both normal and pathological (i.e. parathyroid adenoma or hyperplasia) parathyroid cells $(9-11,15)$, and both cell types reduce their PTH secretion in response to

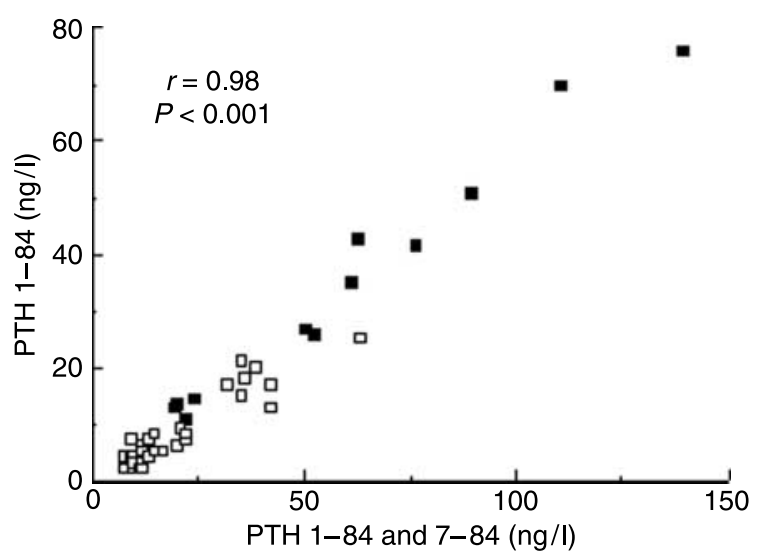

Figure 4 Correlation between serum 'bio-intact' (1-84 PTH) and 'intact' parathyroid hormone (1-84 and 7-84) levels in healthy controls (open squares) and patients with primary hyperparathyroidism (dark squares). a rise in serum calcium either in vitro (30) or in vivo (11, 22, 30-33). However, cells from patients with PHP appear less sensitive to calcium-loading suppression than normal parathyroid cells $(30,32,34,35)$. On this basis calcium-loading suppression tests were proposed as tools for the diagnosis of PHP with various modalities (oral or i.v. loading), timing, and biological criteria (12, 18-23). At the moment, no short-time standardized test is available. The present study was performed to assess the effects of a 3-h standardized i.v. calcium loading on serum PTH levels in a group of healthy volunteers and compare the results to that obtained in a group of patients with PHP.

In another study, using a similar calcium loading procedure, we observed that total plasma calcium levels rose linearly during the infusion and was above $3 \mathrm{mmol} / \mathrm{l}$ an hour after starting the test (unpublished data). Such a plasma calcium level is high enough to suppress normal parathyroid secretion (36). Half-lives of circulating 1-84 and $7-84 \mathrm{PTH}$ are $3-5$ and 10 min respectively $(37,38)$. Thus, measuring serum PTH levels $3 \mathrm{~h}$ after the beginning of calcium load appears to be a relevant timing to evaluate the result of the suppression. Serum i-PTH (1-84 and 7-84) and bi-PTH (1-84) levels are strongly correlated, demonstrating that a PTH assay identifying both 1-84 and 7-84 PTH can be appropriately used to assess parathyroid cell suppression. Similarly, total and ionized calcium are closely correlated, showing that measurement of corrected total plasma calcium is enough to obtain reliable results. The proposed procedure avoids the technical requirements needed for ionized calcium measurements and allows easy performance of this low-cost testing.

$\mathrm{HC}$ and PHP patients exhibit different mean ages and sex ratios. This should be taken in account for the comparison between the two groups studied. Indeed, serum/plasma PTH physiologically rises by about 35\% with age (39-41), which could introduce a limitation to the value of the results. However, the serum/plasma PTH level remains in the normal range of adults and the ability to suppress PTH secretion by calcium does not change with age (41). On the other hand, gender does not appear to significantly modify age-induced changes in PTH secretion $(42,43)$. Our postmenopausal women were taking no hormonal treatments, and hormonal substitution with estrogens has been shown to modulate PTH secretion (44-47). Estrogen therapy reduces the set point of response of PTH secretion to calcium changes by $0.20 \mathrm{mmol} / \mathrm{l}$ (36). A slight difference in parathyroid cell sensitivity to calcium between postmenopausal women with PHP and controls is not excluded but is likely overcome by the rise of $0.9 \mathrm{mmol} / \mathrm{l}$ in plasma calcium levels during the suppression testing. Furthermore, PTH secretion appeared similarly suppressed by increasing calcium level in treated and non-treated women (36). Another potential confounding variable is vitamin D concentration. Plasma vitamin D levels as measured in one half of the patients were in the lowest half of normal 


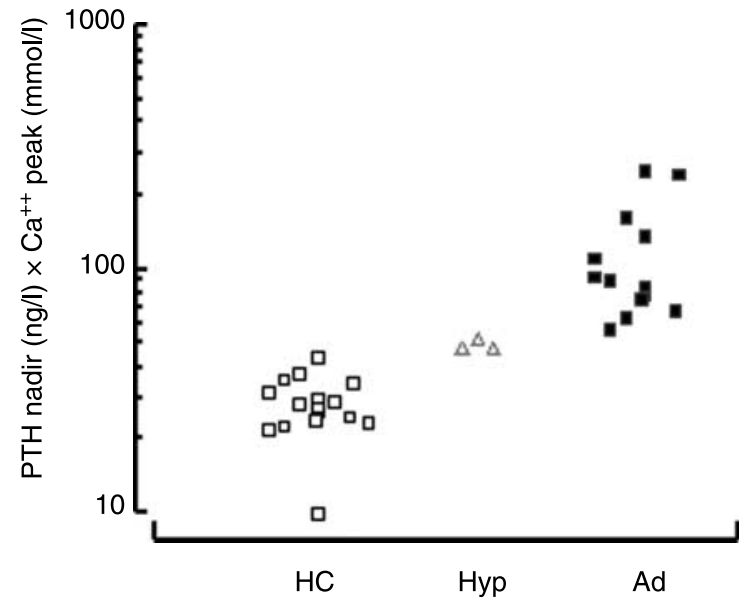

Figure 5 Product of the nadir of serum PTH level (ng/l) by the peak value of plasma calcium ( $\mathrm{mmol} / \mathrm{l})$ in healthy volunteers (open squares), patients with sporadic hyperparathyroidism (dark squares) and patients with MEN1-related hyperparathyroidism (open triangles). The cut-off value between controls and hyperparathyroid patients as a whole is 43 . $\mathrm{HC}$, healthy controls. Hyp, MEN1-related hyperparathyroidism. Ad, adenoma.

range. A vitamin D deficiency, frequently found in patients with PHP (48, 49), cannot be excluded in the other patients. This would lead to a further rise in serum PTH levels. However, previous studies showed that in such cases plasma calcium level was not significantly modified $(48,50)$ and that the ability to suppress PTH secretion by calcium is unchanged (41).

At the end of calcium loading, serum PTH level clearly separates healthy subjects from patients with sporadic PHP (cut-off value $=14 \mathrm{ng} / \mathrm{l}$ ). At this time, the patients with parathyroid hyperplasia related to MEN1 are less easily separated from normal subjects. This is possibly due to a lower sensitivity of adenomatous cells than hyperplastic parathyroid cells to calcium. Among the different mechanisms proposed to explain the relative insensitivity of parathyroid adenomas to calcium $(10,15$, 16,51 ), the changes could be less profound in parathyroid cells from MEN1 patients than in sporadic PHP. However, a study of calcium-sensing receptor content or expression was not performed and this hypothesis cannot be confirmed in our cases. Irrespective of the involved mechanism of PTH insensitivity to calcium, serum PTH levels measured $3 \mathrm{~h}$ after calcium loading rose more rapidly in all PHP patients than in normal subjects. In particular, this pattern was observed in MEN1 patients likely by the occurrence of a rebound in PTH secretion due to parathyroid hyperplasia (22). At this time, controls and all hyperparathyroid patients were clearly separated by PTH levels (cut-off value $=20 \mathrm{ng} / \mathrm{l}$ ). However, it should be emphasized that these cut-off values are only applicable to the tested assay (Advantage iPTH), which is unfortunately no longer available. In addition, a significant shift was observed in this assay between 2003 and 2005 (52), implicating that the cut-off values should be regarded with some caution. To improve the value of these measurements, Hagag et al. proposed to calculate the product $\mathrm{P}=$ peak of $\mathrm{Ca}^{2+}$ nadir of PTH (18). In our series, such calculations did not better separate the two populations than serum PTH level alone (Fig. 5). As to whether measurement of serum PTH value performed at the end of calcium infusion ( $t=3 \mathrm{~h}$ ) appears sufficient to identify sporadic hyperparathyroidism, a determination of serum PTH $3 \mathrm{~h}$ later $(t=6 \mathrm{~h})$ should be preferred in patients suspected for MEN-related hyperparathyroidism.

In conclusion, we describe a standard short-time calcium loading test that is easily performed and has a low cost. The test is well tolerated. However, taking into account the peak of calcemia reached at the end of the infusion, it appears reasonable to keep the patient safely in the department until plasma calcium level has decreased to more physiological value. On the basis of the data obtained in this study such level should be reached $6 \mathrm{~h}$ after the end of the calcium infusion. The measurement of simple parameters, including only corrected total plasma calcium and serum PTH (with an assay identifying PTH 1-84 and its 7-84 fragment) appears sufficient to a relevant performing of this test. It can be carried out in adults without consideration of age and sex, which have a low incidence on the sensitivity of parathyroid secretion to calcium suppression. It is theoretically possible to choose the time of the measurements as a function of the context (sporadic hyperparathyroidism: $+3 \mathrm{~h}$, or MEN: $+6 \mathrm{~h}$ ). However, in the lack of clear context of MEN, both times of measurement $(+3 \mathrm{~h}$ and $+6 \mathrm{~h})$ should be preferred. This test appears to have good sensitivity and specificity for the diagnosis of PHP when the basal biological data (serum PTH level, serum calcium and $24 \mathrm{~h}$ calciuria) do not allow a clear diagnosis.

\section{Acknowledgements}

We would like to acknowledge Mrs O Vandapel for her technical assistance and Mrs C Boulard, L Gutierrez, and $C$ Schaffter for their efficient roles in the realization of this study.

\section{References}

1 Bilezikian JP, Brandi ML, Rubin M \& Silverberg SJ. Primary hyperparathyroidism: new concepts in clinical densitometric and biochemical features. Journal of Internal Medicine 2005257 6-17.

2 Bilezikian JP \& Silverberg SJ. Asymptomatic primary hyperparathyroidism. New England Journal of Medicine $20043501746-$ 1751.

3 Resnick LM \& Laragh JH. Calcium metabolism and parathyroid function in primary hyperparathyroidism. American Journal of Medicine 198578 385-390.

4 Silverberg SJ \& Bilezikian JP. 'Incipient' primary hyperparathyroidism: a 'forme fruste' of an old disease. Journal of Clinical Endocrinology and Metabolism $2003 \mathbf{8 8} 5348-5352$. 
5 Hollenberg AN \& Arnold A. Hypercalcemia with low-normal serum intact PTH: a novel presentation of primary hyperparathyroidism. American Journal of Medicine 199191 547-548.

6 Rao DS, Phillips ER, Divine GW \& Talpos GB. Randomized controlled clinical trial of surgery versus no surgery in patients with mild asymptomatic primary hyperparathyroidism. Journal of Clinical Endocrinology and Metabolism 200489 5415-5422.

7 Nilsson IL, Yin L, Lundgren E, Rastad J \& Ekbom A. Clinical presentation of primary hyperparathyroidism in Europe-nationwide cohort analysis on mortality from nonmalignant causes. Journal of Bone and Mineral Research 200217 N68-N74.

8 Nilsson IL, Aberg J, Rastad J \& Lind L. Maintained normalization of cardiovascular dysfunction 5 years after parathyroidectomy in primary hyperparathyroidism. Surgery 2005137 6321-6638.

9 Gogusev J, Duchambon P, Hory B, Giovannini M, Goureau Y, Sarfati E \& Drueke TB. Depressed expression of calcium receptor in parathyroid gland tissue of patients with hyperparathyroidism. Kidney International 199751 328-336.

10 Farnebo F, Enberg U, Grimelius L, Backdahl M, Schalling M, Larsson C \& Farnebo LO. Tumor-specific decreased expression of calcium sensing receptor messenger ribonucleic acid in sporadic primary hyperparathyroidism. Journal of Clinical Endocrinology and Metabolism 199782 3481-3486.

11 Cetani F, Picone A, Cerrai P, Vignali E, Borsari S, Pardi E, Viacava P, Naccarato AG, Miccoli P, Kifor O, Brown EM, Pinchera A \& Marcocci C. Parathyroid expression of calcium-sensing receptor protein and in vivo parathyroid hormone- $\mathrm{Ca}^{2+}$ set-point in patients with primary hyperparathyroidism. Journal of Clinical Endocrinology and Metabolism 200085 4789-4794.

12 Bergenfelz A, Valdermarsson S \& Ahren B. Suppression by calcium of serum levels of intact parathyroid hormone in primary hyperparathyroidism. Hormone Research 199339 146-151.

13 Khosla S, Ebeling PR, Firek AF, Burritt MM, Kao PC \& Heath H, III. Calcium infusion suggests a set-point abnormality of parathyroid gland function in familial benign hypercalcemia and more complex disturbances in primary hyperparathyroidism. Journal of Clinical Endocrinology and Metabolism 1993 76 715-720.

14 Nygren P, Gylfe E, Larsson R, Johansson H, Juhlin C, Klareskoq L, Akerstrom G \& Rastad J. Modulation of the $\mathrm{Ca}^{2+}$-sensing function of parathyroid cells in vitro and hyperparathyroidism. Biochimica et Biophysica Acta 1998968 253-260.

15 Corbetta S, Mantovani G, Lania A, Borgato S, Vicentini L, Beretta E, Faglia G, Di Blasio AM \& Spada A. Calcium-sensing receptor expression and signaling in human parathyroid adenomas and primary hyperplasia. Clinical Endocrinology 200052 339-348.

16 Yano S, Sugimoto T, Tsukamoto T, Chihara K, Kobayashi A, Kitazawa S, Maeda S \& Kitazawa R. Decrease in vitamin D receptor and calcium-sensing receptor in highly proliferative parathyroid adenomas. European Journal of Endocrinology 2003148 403-411.

17 Broadus AE, Deftos LJ \& Bartter FC. Effects of the intravenous administration of calcium on nephrogenous cyclic AMP: use as a parathyroid suppression test. Journal of Clinical Endocrinology and Metabolism 197846 477-487.

18 Hagag P, Revet-Zak I, Hod N, Horne T, Rapoport MJ \& Weiss M. Diagnosis of normocalcemic hyperparathyroidism by oral calcium loading test. Journal of Endocrinological Investigation $2003 \mathbf{2 6}$ 327-332.

19 Monchik JM, Lamberton RP \& Ruth U. Role of the oral calciumloading test with measurement of intact parathyroid hormone in the diagnosis of symptomatic subtle primary hyperparathyroidism. Surgery 1992112 1103-1109.

20 Carmignani G, Belgrano E, Puppo P, Repetto U, Giusti M, Giordano G \& Giuliani L. PTH radioimmunoassay and loading tests in the diagnosis of patients with primary hyperparathyroidism. European Urology 19828 102-108.

21 Bevilacqua M, Dominguez LJ, Righini V, Valdes V, Vago T, Leopaldi E, Baldi G, Barrella M \& Barbagallo M. Dissimilar PTH, gastrin, and calcitonin responses to oral calcium and peptones in hypocalciuric hypercalcemia, primary hyperparathyroidism, and normal subjects: a useful tool for differential diagnosis. Journal of Bone and Mineral Research: 200621 406-412.

22 McHenry CR, Rosen IB, Walfish PG \& Pollard A. Oral calcium load test: diagnostic and physiologic implications in hyperparathyroidism. Surgery $1990 \mathbf{1 0 8} 1026-1031$.

23 Lepage R, Whittom S, Bertrand S, Bashali G \& D'Amour P. Superiority of dynamic over static reference intervals for intact, midmolecule, and C-terminal parathyrin in evaluating calcemic disorders. Clinical Chemistry 199238 2129-2135.

24 Howard JE, Hopkins TR \& Connor TB. On certain physiologic responses to intravenous administration of calcium salts into normal, hyperrathyroid and hypoparathyroid persons. Journal of Clinical Endocrinology and Metabolism 1953 13 1-19.

25 Khosla S, Melton L III, Wermers RA, Crowson CS, O'Fallon W \& Riggs B. Primary hyperparathyroidism and the risk of fracture: a population-based study. Journal of Bone and Mineral Research 1999 14 1700-1704.

26 Vestergaard P, Mollerup CL, Frockjaer VG, Christiansen P, BlichertToft M \& Mosekilde L. Cohort study of risk of fracture before and after surgery for primary hyperparathyroidism. BMJ 2000321 598-602.

27 NIH Conference. Diagnosis and management of asymptomatic primary hyperparathyroidism: consensus development conference statement. Annals of Internal Medicine 1991114 593-597.

28 Bilezikian JP, Potts JT Jr, Fuleihan Gel H, Kleerekoper M, Neer R, Peacock M, Rastad J, Silverberg SJ, Udelsman R \& Wells SA. Summary statement from a workshop on asymptomatic primary hyperparathyroidism: a perspective for the 21 st century. Journal of Clinical Endocrinology and Metabolism $2002 \mathbf{8 7}$ 5353-5361.

29 Calzada-Nocaudie M, Chanson P, Conte-Devolx B, Delemer B, Estour B, Henry JF, Houillier P, Kraimps JL, Ribot C, Rohmer V, Tabarin A, Verges B, Vidal-Trecan G, Wemeau JL \& Weryha G. Management of asymptomatic primary hyperparathyroidism, French Society of Endocrinology consensus. Annales d'Endocrinologie 200667 7-12.

30 Brown EM, Broadus AE, Brennan MF, Gardner DG, Marx SJ, Spiegel A, Downs RW Jr, Attie M \& Aurbach GD. Direct comparison in vivo and in vitro of suppressibilty of parathyroid function by calcium in primary hyperparathyroidism. Journal of Clinical Endocrinology and Metabolism $1979 \mathbf{4 8} 604-618$.

31 Cirillo M, Strazzullo P, Mattioli PL, Siani A \& Cioffi G. Basal parathyroid activity and renal calcium handling during an intravenous calcium load. Nephron 198438 167-169.

32 Ramirez JA, Goodman WG, Gornbein J, Menezes C, Moulton L, Segre GV \& Salusky IB. Direct in vivo comparison of calciumregulated parathyroid hormone secretion in normal volunteers and patients with secondary hyperparathyroidism. Journal of Clinical Endocrinology and Metabolism 199376 1489-1494.

33 Ortolani S, Scotti A \& Cherubini R. Rapid suppression of bone resoption and parathyroid hormone secretion by acute oral administration of calcium in healthy adult men. Journal of Endocrinological Investigation 200326 353-358.

34 Lips P, Netelenbos JC, van Doorn L, Hackeng WH \& Lips CJ. Stimulation and suppression of intact parathyroid hormone (PTH 1-84) in normal subjects and in hyperparathyroid patients. Clinical Endocrinology 199135 35-40.

35 McCarron DA, Muther RS, Lenfesty B \& Bennett WM. Parathyroid function in persistant hyperparathyroidism: relationship to gland size. Kidney International 198222 662-670.

36 Boucher A, D'Amour P, Hamel L, Fugère P, Gascon-Barré M, Lepage R \& Ste-Marie LG. Estrogen replacement decreases the set point of parathyroid hormone stimulation by calcium in normal postmenopausal women. Journal of Clinical Endocrinology and Metabolism 198968 831-836.

37 Bieglmayer C, Prager G \& Niederle B. Kinetic analyses of parathyroid hormone clearance as measured by three rapid immunoassays during parathyroidectomy. Clinical Chemistry 200248 1731-1738. 
38 Yamashita H, Gao P, Cantor T, Futata T, Murakami T, Uchino S, Wanatabe S, Kawamoto H, Fukagawa M \& Noguchi S. Large carboxy-terminal parathyroid hormone (PTH) fragment with a relatively longer half-life than 1-84 PTH is secreted directly from the parathyroid glands in humans. European Journal of Endocrinology $2003149301-306$.

39 Sherman SS, Holis BW \& Tobin JD. Vitamin D status and related parameters in a healthy population: effects of age, sex and season. Journal of Clinical Endocrinology and Metabolism 199071 405-413.

40 Eastell R, Yergey AL, Vieira NE, Cedel SL, Kumar R \& Riggs BL. Interrelationship among vitamin $\mathrm{D}$ metabolism, true calcium absorption, parathyroid function, and age in women: evidence of an age-related intestinal resistance to 1,25-dihydroxyvitamin D action. Journal of Bone and Mineral Research 19916 125-132.

41 Quesada JM, Coopmans W, Ruiz B, Aljama P, Jans I \& Bouillon R. Influence of vitamin D on parathyroid function in the elderly. Journal of Clinical Endocrinology and Metabolism 1992 75 494-501.

42 Haden ST, Brown EM, Hurwitz S, Scott J \& El-Hajj Fuleihan G. The effects of age and gender on parathyroid hormone dynamics. Clinical Endocrinology 200052 329-338.

43 Khosla S, Melton LJ III, Atkinson EJ, O’Fallon WM, Klee GG \& Riggs BL. Relationship of serum sex steroid levels and bone turnover markers with bone mineral density in men and women: a key role for bioavailable estrogen. Journal of Clinical Endocrinology and Metabolism $1998 \mathbf{8 3} 2266-2274$.

44 Selby PL \& Peacock M. The effects of transdermal oestrogens on bone, calcium-regulating hormones and liver in postmenopausal women. Clinical Endocrinology 198625 543-547.

45 Prince RL, Schiff I \& Neer RM. Effects of transdermal estrogen replacement on parathyroid hormone secretion. Journal of Clinical Endocrinology and Metabolism 199071 1284-1287.

46 Harms HM, Neubauer O, Kayser C, Wustermann PR, Horn R, Brosa U, Schlinke E, Kulpmann WR, von zur Muhlen A \&
Hesch RD. Pulse amplitude and frequency modulation of parathyroid hormone in early postmenopausal women before and on hormone replacement therapy. Journal of Clinical Endocrinology and Metabolism $1994 \mathbf{7 8} 48-52$.

47 Khosla S, Atkinson EJ, Melton LJ III \& Riggs BL. Effects of age and estrogen status on serum parathyroid hormone levels and biochemical markers of bone turnover in women: a populationbased study. Journal of Clinical Endocrinology and Metabolism 1997 82 1522-1527.

48 Silverberg SJ, Shane E, Dempster DW \& Bilezikian JP. The effects of vitamin D insufficiency in patients with primary hyperparathyroidism. American Journal of Medicine 1999107 561-567.

49 Boudou P, Ibrahim F, Cormier C, Sarfati E \& Souberbielle JC. A very high incidence of low 25 hydroxy-vitamin D serum concentration in a French population of patients with primary hyperparathyroidism. Journal of Endocrinological Investigation 200629 511-515.

50 Maruani G, Hertig A, Paillard M \& Houillier P. Normocalcemic primary hyperparathyroidism: evidence for a generalized targettissue resistance to parathyroid hormone. Journal of Clinical Endocrinology and Metabolism 200288 4641-4648.

51 Yamauchi M, Sugimoto T, Yamagushi T, Yano S, Kanzawa M, Kobayashi A \& Chihara K. Association of polymorphic alleles of the calcium-sensing receptor gene with the clinical severity of primary hyperparathyroidism. Clinical Endocrinology $2001 \mathbf{5 5}$ 373-379.

52 Cantor T. Parathyroid hormone assay drift: an unappreciated problem in dialysis patient management. Seminars in Dialysis $200518359-364$.

Received 2 March 2007

Accepted 31 May 2007 